\title{
THE EFFECT OF GREEN ACCOUNTING PRACTICES AND ORGANIZATIONAL SIZE IN BUSINESS SUSTAINABILITY OF PUBLIC HOSPITALS
}

\author{
Muhammad Hasyim Ashari*1), and Yudhi Anggoro ${ }^{2)}$ \\ Sekolah Tinggi Ilmu Ekonomi Indocakti Malang ${ }^{1,2)}$ \\ muhammadhasyimashari@gmail.com ${ }^{1)}$,idhuy2000@gmail.com ${ }^{2)}$
}

\begin{abstract}
To realize business continuity in public hospital institutions, an analysis is needed to be related to the green accounting practices in public hospitals considering the environmental and social impacts caused by their business activities, in addition to the different types (classes) of public hospitals, an analysis is needed regarding the size of the organization of the house. So, this study aims to analyze the effect of green accounting practices and organizational size on business sustainability in public hospitals in Malang Raya. This research is a survey research using descriptive and correlational quantitative approaches. The questionnaire was used to collect data from public hospitals in Malang District, Malang City, and Batu City. A probability sample is used in sample selection with a cluster random sampling technique. The results show that partially the green accounting practices affect business sustainability, while the size of the organization does not affect business sustainability. Simultaneously, the green accounting practices and organizational size has no effect on business sustainability, and this is indicated by the small contribution of the effect of only ten point five percent.
\end{abstract}

Keywords: Green Accounting; Organizational Size; Business Sustainability

*Corresponding author

Email: muhammadhasyimashari@gmail.com

DOI: https://doi.org/10.33369/j.akuntansi.11.1.1-15

\section{INTRODUCTION}

The business sustainability concept assumes that a business will remain in business in the future. Business sustainability is a reflection of determining ways or actions to fulfill, maintain, develop and protect the resources of a business in the current state (Handayani, 2007). Business sustainability focuses on achieving financial performance by maintaining long-term growth and profitability and non-financial performance that promotes the effectiveness of corporate governance, ethical behavior, and social and environmental responsibility (Rezaee, 2015). To achieve this, the company in its business management must maintain a balance of interests between the company's economy, environment, and society (Miqdad, 2016). This can be done by applying green accounting which is expected to have an impact on the sustainability of a company's business.

The green accounting practices is expected to have an impact on improving the company's image so that the company will be more trusted by stakeholders with the aim of long-term business sustainability (Setiawan, 2014); (Panggabean \& Deviarti, 2012), increase company performance and value, and reduces company risk (Lako, 2015a, 2015b), and is certainly expected to have a significant effect on the company's financial position (Hansen \& Mowen, 2009). For this reason, the company must have the ability to manage company finances so that with sufficient funds in running and developing its business by minimizing all the negative impacts caused by its business operations on the environment and also its social community in the hope that the next generation as a successor can have resources. adequate for long-term needs.

Also, in realizing business sustainability, it is necessary to consider organizational size as another factor, because as we know that large companies compared to small companies have large resources to finance the availability of this information so that they can reveal more 
information ( Ijma, et., al., 2018). To reduce the environmental impact resulting from their business activities, large organizations must have the ability to finance and provide labor for these activities (Hackston \& Milne, 1996); (Frost \& Seamer, 2002). So, with this in realizing long-term business sustainability. The object of this research consists of public hospitals located in Malang Raya, namely those in Malang District, Malang City, and Batu City - East Java, Indonesia. The purpose of this study was to determine and analyze the effect of green accounting practices and organization size on business sustainability.

The hope is that in the future public hospitals, especially those in the Malang Raya area, can apply green accounting to be able to maintain long-term business sustainability. The choice of research object is because the concept of green accounting can also be applied in public hospitals as a public entity (Deegan, 2003), besides that public hospitals strive to maintain environmental health by the provisions of Law Number 36 of the Year 2009 concerning Health which is strengthened through a Regulation Government Number 66 of the Year 2014 concerning Environmental Health and also Regulation of the Minister of Health of the Republic of Indonesia Number 7 of the Year 2019 concerning Hospital Environmental Health which aims to realize the quality of hospital environmental health and the social community consisting of hospital human resources, patients, visitors and the community around the hospital, as well as realizing an environmentally friendly hospital, and also based on the research of Putri, et., al., (2016) which states that hospitals in Malang currently still show an average level of readiness that is in trouble. environment to the green hospital. Also, 40 public hospitals have different types (classes) in Malang Raya, namely, type (class) A there are 1 hospital, type (class) B there are 8 hospitals, with type (class) $\mathrm{C}$ there are 13 hospitals, and 18 hospitals of type (class) D. So that the different types of public hospitals can show the size of the hospital organization for each type of hospital that is the object of the study.

The novelty of this research is the use of green accounting which includes financial, social, and environmental aspects in measuring the performance of public hospitals in Malang Raya by taking into account the size of the organization of each public hospital which is the object of the study.

\section{RESEARCH METHODS}

This survey research was conducted by distributing questionnaires to respondents as the research sample. The approach is carried out with descriptive quantitative (Arikunto, 2005) and correlational (Hamzah, 2019), namely multivariate correlational (causal correlation) using multiple linear regression tests. The public hospital (RSU) located in Malang Raya is the object of this research. In total, there are 40 public hospitals spread across Malang (District and City) and Batu City. Probability sampling is used in determining the number of samples in a way that each member of the population is given the same opportunity to become a member of the sample. The sampling technique was cluster random sampling, taking into account the spread of a population that was spread over 22 hospitals in Malang District, 13 hospitals in Malang City, and 5 hospitals in Batu City. Each research object has a different type, namely type A with 1 hospital, type B with 8 hospitals, type $\mathrm{C}$ with 13 hospitals, and type $\mathrm{D}$ with 18 hospitals. The samples collected were 39 public hospitals with details of 1 hospital is type A, 8 hospitals are type $\mathrm{B}, 13$ hospitals is type $\mathrm{C}$, and 17 hospitals are type $\mathrm{D}$. The public hospitals that were the samples of the study were scattered in Malang Regency with a total of 21 RSUs, in Malang City several 13 RSUs and Batu City several 5 RSUs. The number of samples collected was around $97.5 \%$ from the population as in Table 1. 
Table 1. Population and Samples Data in Public Hospitals

\begin{tabular}{lcccccccc}
\hline \multirow{2}{*}{$\begin{array}{c}\text { Population and } \\
\text { Sample Data }\end{array}$} & $\begin{array}{c}\text { Malang } \\
\text { District }\end{array}$ & $\begin{array}{c}\text { Malang } \\
\text { City }\end{array}$ & $\begin{array}{c}\text { Batu } \\
\text { City }\end{array}$ & A & B & C & D & \multirow{2}{*}{ Number of } \\
\hline Population & 22 & 13 & 5 & 1 & 8 & 13 & 18 & 40 \\
Sampels & 21 & 13 & 5 & 1 & 8 & 13 & 17 & 39 \\
Persentage (\%) & 95,5 & 100 & 100 & 100 & 100 & 100 & 94,4 & 97,5 \\
\hline
\end{tabular}

Source: Primary Data, 2020

The number of research samples is following the provisions of Cohen, et., al., (2007), as well as Baley and Gay in Mahmud (2011) which explains that the minimum sample size in a study is 30 subjects, and also based on the table of Isacc and Michael (1981). ) that is, if the population is 40 , a minimum of 38 samples are required with an error rate of $1 \%$, or a minimum of 36 samples is needed if the error rate is $5 \%$ and $10 \%$ (Sugiyono, 2010). This is in line with the table Krejcie and Morgan (1970) which shows that the required sample size from a population of 40, 36 samples are needed with a confidence level of 95\% (Sugiyono, 2005).

This study uses primary data in the form of answers to questionnaires given to respondents who have been accompanied by questionnaire filling procedures and a brief explanation of the research objectives. Meanwhile, secondary data in the form of documents or data used to answer questions that arise as research problems. The questionnaire used in this study is a standardized questionnaire (Morrisan, 2012), and is closed by asking the respondents multiple-choice questions (Siregar, 2013). The Likert scale number of points 7 is used to measure research instruments as the development of Hofmans, et., al., (2007) and Budiaji (2013) which explains the Likert scale with the number of points 7 is preferred by respondents and the use of the number of points 7 has a validity index, reliability, strength of discrimination, and good stability.

Tabel 2. Likert Scale

\begin{tabular}{lcc}
\hline \multicolumn{1}{c}{ Alternative Answers } & Score \\
\hline Strongly Disagree & STS & 1 \\
Disagree & TS & 2 \\
Disagree Less & KS & 3 \\
Doubtful & R & 4 \\
Simply Agree & CS & 5 \\
Agree & S & 6 \\
Strongly Agree & SS & 7 \\
\hline Source: Sugiyono, 2010, modified by researchers based on Hofmans, et.,
\end{tabular}

The purpose of this study was to examine the influence of green accounting practices and organizational size on the business sustainability variable that occurred in the Public Hospitals of Malang Raya. The green accounting practices is defined as the existence of company activities related to financial, social, and environmental activities whose reporting is conveyed in the form of complete, integrated, and relevant accounting information as green accounting reporting which has benefits for users of these financial statements in assessments and making a decision related to economic and non-economic factors as a form of corporate responsibility in terms of economy (profit), social (people) and environment (planet).

The variables of the green accounting practices in their measurement use indicators that are grouped into financial, social, and environmental aspects. The financial aspect includes financial reporting and financial statement audits (Statement of Financial Accounting Standards No.1 and Susilo (2008)). The social aspects include corporate social responsibility, social activity reporting, and social auditing (Chahal \& Sharma (2006), Puspitaningtyas (2016), Teoh, 
et. al., (1984) in Astiti (2014) and Hati (2018) ). Whereas the environmental aspect includes: attention to the environment, involvement in environmental problems, responsibility for the environment, reporting of environmental problems, and environmental audits (Teoh, et. al., (1984) in Yousef (2003), in Susilo (2008), in Astiti (2014), Dalam Hati (2018), Dunk (2002), Suaryana (2011), and ISO series 14010-14019 on Environmental Audit). This indicator has been used by Ashari (2019); Ashari, et., al., (2020); Ashari \& Anggoro (2020) in one set of indicators of the variable application of green accounting. Whereas organizational size is a scale that shows the size of a company seen from the number of employees, sales volume, and value of assets owned. In this study, organizational size is used to determine the size of the company, seen from the number of employees, sales volume, and asset value (Pinasti, 2001; Ashari, 2019; Ashari, et., al., 2020). The number of employees is divided based on Ayyagari, et., al., (2011) and the sales volume and asset value are based on Law Number 20 of 2008 concerning Micro, Small, and Medium Enterprises.

Meanwhile, business sustainability is defined as the company's ability to manage company finances so that it has sufficient funds to run and develop its business activities by taking actions that minimize any adverse impacts on the environment and also the social community with the aim that the next generation will have adequate resources sufficient for long-term needs. The indicators used in measuring business sustainability variables are the sustainability of capital, the sustainability of human resources, the sustainability of services, and sustainability of sales (Handayani, 2007; Ashari, 2019; Ashari \& Anggoro, 2020). below:

The description of the conceptual framework in this study is illustrated in Figure 1

\begin{tabular}{|c|c|c|}
\hline $\begin{array}{l}\qquad \text { X1 } \\
\qquad \text { Green Accounting Practices } \\
\text { Financial Aspect } \\
\text { 1. Financial Reporting } \\
\text { 2. Financial Report Audit }\end{array}$ & & $\begin{array}{l}\qquad \begin{array}{c}\text { X2 } \\
\text { Organizational Size }\end{array} \\
\text { 1. Number of Employees } \\
\text { 2. Sales Volume } \\
\text { 3. Asset Value }\end{array}$ \\
\hline $\begin{array}{l}\text { Social Aspects } \\
\text { 3. Corporate Social Responsibility }\end{array}$ & & $\mathrm{H} 2$ \\
\hline $\begin{array}{l}\text { 4. Social Activity Reporting } \\
\text { 5. Social Audit } \\
\text { Environmental Aspects }\end{array}$ & H1 & $\begin{array}{c}\mathrm{Y} \\
\text { Business Sustainability }\end{array}$ \\
\hline $\begin{array}{ll}\text { 6. } & \text { Attention to the environment } \\
\text { 7. } & \text { Involvement in environmental issues } \\
\text { 8. } & \text { Environmental responsibility } \\
\text { 9. } & \text { Reporting environmental problems } \\
\text { 10. } & \text { Environmental audits }\end{array}$ & & $\begin{array}{l}\text { 1. Sustainability of Capital } \\
\text { 2. Sustainability of Human Resources } \\
\text { 3. Sustainability of Services } \\
\text { 4. Sustainability of Continuity }\end{array}$ \\
\hline
\end{tabular}

Figure 1. Conceptual Framework

Source: Researcher, 2020 study are:

So, based on the description and conceptual framework, the hypotheses built in this $\mathrm{H}_{1}$ : Green accounting practices affect business sustainability.

$\mathrm{H}_{2}$ : The organizational size has an affects on business sustainability.

$\mathrm{H}_{3}$ : The green accounting practices and the organizational size simultaneously affect business sustainability.

Furthermore, the data that has been collected is analyzed using statistical tools in the form of SPSS 25 for Windows as data processing software to test the validity, reliability test, 
classical assumption test, and hypothesis testing, which can then be made analysis and conclusions from the results of the study.

\section{RESULTS AND DISCUSSION \\ Respondent Characteristics}

The number of respondents in this study was 39 public hospitals out of 40 public hospitals in the Malang Raya area (see table 3). There is only 1 public hospital that does not provide answers to research questionnaires because the data owned by the hospital must be reported to the central office first. Respondents collected came from hospitals in Malang District with a total of 21 public hospitals, 13 public hospitals in Malang City, and 5 public hospitals in Batu City. Consisting of 1 public hospital is type A, 8 public hospitals are type B, 13 public hospitals is type $\mathrm{C}$ and 17 public hospitals is type $\mathrm{D}$.

Table 3. Respondents Data

\begin{tabular}{lccccc}
\hline Region / Location & \multicolumn{4}{c}{ Type / Class } & Number of \\
Public Hospitals & A & B & C & D & Respondents \\
\hline Malang District & - & 3 & 6 & 12 & 21 \\
Malang City & 1 & 5 & 5 & 2 & 13 \\
Batu City & - & - & 2 & 3 & 5 \\
\hline \multicolumn{1}{c}{ Total } & 1 & 8 & 13 & 17 & 39 \\
\hline Source: Primary Data, 2020 & & & & &
\end{tabular}

The characteristics of the respondents who filled out the questionnaire in this study are presented in table 4, namely $35.90 \%$ male and $64.10 \%$ female, with educational levels ranging from D3, S1, and S2 levels and 28 people have understanding in the field of accounting and 11 people have an understanding of management. The respondents were between 23 and 53 years old and had work experience between 1 and 15 years. Respondents of this study have 2 positions as SPI (Internal Supervisory Unit), 22 Accounting and Finance Staff, 11 Managers or Heads of Divisions, and the remaining 3 as Directors. With a description of the characteristics of these respondents, it can be seen that the respondents who filled out the questionnaire had the ability and understanding of green accounting practices to the hospital where they worked and understood the size of the hospital organization.

Table 4. Characteristics of Respondents

\begin{tabular}{lrr}
\hline \multicolumn{1}{c}{ Characteristics of Respondents } & Number of & Percentage (\%) \\
\hline Gender & 14 & 35.90 \\
Male & 25 & 64.10 \\
Female & 39 & 100.00 \\
Number of Genders & & \\
\hline Level of Education & 5 & 12.82 \\
S2 - Strata 2 & 25 & 64.10 \\
S1 - Strata 1 & 9 & 23.08 \\
D3 - Diploma 3 & 39 & 100.00 \\
Number of Level of Education & & \\
\hline Field of Education & 28 & 71.79 \\
Accounting & 11 & 28.21 \\
Management & 39 & 100.00 \\
Number of Field of Education & & \\
\hline Age & 13 & 33.33 \\
$\geq 23$ - 30 years & 20 & 51.28 \\
$>$ 30 - 40 years & 4 & 10.26 \\
$>40$ - 50 years & 2 & 5.13 \\
50 years & 39 & 100.00 \\
\hline Number of Age & & \\
\hline Years of Service & 13 & 33.33 \\
$\geq 1$ - 3 years & &
\end{tabular}


THE EFFECT OF GREEN ACCOUNTING PRACTICES AND ORGANIZATIONAL SIZE IN BUSINESS

SUSTAINABILITY OF PUBLIC HOSPITALS

Muhammad Hasyim Ashari, and Yudhi Anggoro

\begin{tabular}{lrr}
\hline \multicolumn{1}{c}{ Characteristics of Respondents } & Number of & Percentage (\%) \\
\hline$>3$ - 6 years & 15 & 38.46 \\
$>$ 6 - 10 years & 6 & 15.39 \\
$>10$ - 15 years & 5 & 12.82 \\
Number of Years of Service & 39 & 100.00 \\
\hline Position & & \\
Director of Finance and Accounting & 3 & 7.69 \\
Manager or Head of Section / Unit & 11 & 28.21 \\
Accounting Staff & 11 & 28.21 \\
Financial Staff & 12 & 30.76 \\
SPI (Internal Supervisory Unit) & 2 & 5.13 \\
Number of Position & 39 & 100.00 \\
\hline Source: Primary Data, 2020
\end{tabular}

Source: Primary Data, 2020

\section{Validity and Reliability Test}

The initial stage of the test is the validity test for the variable of green accounting practices, the variable of organizational size, and the variable of business sustainability.

Table 5. Validity Test Results of Green Accounting Practices Variables

\begin{tabular}{|c|c|c|c|c|}
\hline Items & r_Table & r_Count & Sig. & Criteria \\
\hline 1 & 0.316 & 0.644 & 0.000 & Valid \\
\hline 2 & 0.316 & 0.889 & 0.000 & Valid \\
\hline 3 & 0.316 & 0.560 & 0.000 & Valid \\
\hline 4 & 0.316 & 0.352 & 0.028 & Valid \\
\hline 5 & 0.316 & 0.371 & 0.020 & Valid \\
\hline 6 & 0.316 & 0.453 & 0.004 & Valid \\
\hline 7 & 0.316 & 0.477 & 0.002 & Valid \\
\hline 8 & 0.316 & 0.350 & 0.029 & Valid \\
\hline 9 & 0.316 & 0.351 & 0.028 & Valid \\
\hline 10 & 0.316 & 0.425 & 0.007 & Valid \\
\hline 11 & 0.316 & 0.658 & 0.000 & Valid \\
\hline 12 & 0.316 & 0.561 & 0.000 & Valid \\
\hline 13 & 0.316 & 0.665 & 0.000 & Valid \\
\hline 14 & 0.316 & 0.871 & 0.000 & Valid \\
\hline 15 & 0.316 & 0.874 & 0.000 & Valid \\
\hline 16 & 0.316 & 0.368 & 0.021 & Valid \\
\hline 17 & 0.316 & 0.408 & 0.010 & Valid \\
\hline 18 & 0.316 & 0.538 & 0.000 & Valid \\
\hline 19 & 0.316 & 0.720 & 0.000 & Valid \\
\hline 20 & 0.316 & 0.557 & 0.000 & Valid \\
\hline 21 & 0.316 & 0.785 & 0.000 & Valid \\
\hline 22 & 0.316 & 0.847 & 0.000 & Valid \\
\hline 23 & 0.316 & 0.463 & 0.003 & Valid \\
\hline 24 & 0.316 & 0.406 & 0.010 & Valid \\
\hline 25 & 0.316 & 0.698 & 0.000 & Valid \\
\hline 26 & 0.316 & 0.871 & 0.000 & Valid \\
\hline 27 & 0.316 & 0.716 & 0.000 & Valid \\
\hline 28 & 0.316 & 0.687 & 0.000 & Valid \\
\hline 29 & 0.316 & 0.830 & 0.000 & Valid \\
\hline 30 & 0.316 & 0.851 & 0.000 & Valid \\
\hline 31 & 0.316 & 0.890 & 0.000 & Valid \\
\hline
\end{tabular}

Based on table 5, with a total sample size (N) of 39 public hospitals in Malang Raya at a significance of 5\%, it is known that the r-table value of 0.316 indicates that the results of the validity test of 31 instruments on the variable of green accounting practices all produce r_Count $>$ of r_Table. Likewise, if you look at the Significance value (Sig.) which shows that the 31 
instruments used are worth $<0.05$. This explains that all instruments used by the green accounting practices variable can be said to be valid.

Whereas for the validity test of the organizational size variable presented in table 6 with the same sample, it is known that for the 3 instruments used it is known that the value of r_Count $>$ r_Table, and also the significance value (Sig.) shows a value of $<0.05$. Thus, this value indicates that the instruments used by the organizational size variable can be declared valid.

Table 6.Validity Test Results for Organizational Size Variables

\begin{tabular}{ccccc}
\hline Items & r_Table & r_Count & Sig. & Criteria \\
\hline 1 & 0.316 & 0.819 & 0.000 & Valid \\
2 & 0.316 & 0.959 & 0.000 & Valid \\
3 & 0.316 & 0.943 & 0.000 & Valid \\
\hline
\end{tabular}

For the business sustainability variable, the validity test was carried out on the 12 instruments used as presented in table 7 and it is known that the value of r_Count $>r_{-}$Table. The value of $r_{-}$Table from a sample of 39 public hospitals with a significance level of 5\%. This shows that the instrument used in the business sustainability variable in this study is declared valid. Moreover, it is proven by the Significance value (Sig.) of all instruments used which shows a value $<0.05$ as shown in Table 7.

Table 7.Validity Test Results of Business Sustainability Variables

\begin{tabular}{ccccc}
\hline Items & r_Tabel & r_Count & Sig. & Criteria \\
\hline 1 & 0.316 & 0.689 & 0.000 & Valid \\
2 & 0.316 & 0.869 & 0.000 & Valid \\
3 & 0.316 & 0.814 & 0.000 & Valid \\
4 & 0.316 & 0.773 & 0.000 & Valid \\
5 & 0.316 & 0.806 & 0.000 & Valid \\
6 & 0.316 & 0.511 & 0.001 & Valid \\
7 & 0.316 & 0.501 & 0.001 & Valid \\
8 & 0.316 & 0.759 & 0.000 & Valid \\
9 & 0.316 & 0.482 & 0.002 & Valid \\
10 & 0.316 & 0.406 & 0.010 & Valid \\
11 & 0.316 & 0.342 & 0.033 & Valid \\
12 & 0.316 & 0.381 & 0.017 & Valid \\
\hline
\end{tabular}

The next stage is to test the reliability of the green accounting practices, organizational size, and business sustainability variables as shown in table 8 , showing the results where the green accounting practices variable, organizational size variable, and the business sustainability variable produces a Cronbach`s Alpha value of $>0.60$, namely 0.943 in sequence; 0.881 ; and 0.857 , so that all research instruments in the research variables were declared reliable.

Table 8. Reliability Test Results

\begin{tabular}{lcccc}
\hline \multicolumn{1}{c}{ Variable } & Cronbach's Alpha & N of Items & Criteria \\
\hline X1 Green Accounting Practices & 0.943 & 31 & Reliable \\
X2 Organizational Size & 0.881 & 3 & Reliable \\
Y Business Sustainability & 0.857 & 12 & Reliable \\
\hline
\end{tabular}

\section{Classic Assumption Test}

The classical assumption test is carried out in several stages including the normality test, multicollinearity test, heteroscedasticity test, and autocorrelation. The normality test shows that the plotting of data points has followed the diagonal line as shown in Figure 2 which identifies the normal distribution of the regression model (Ghazali, 2011). 


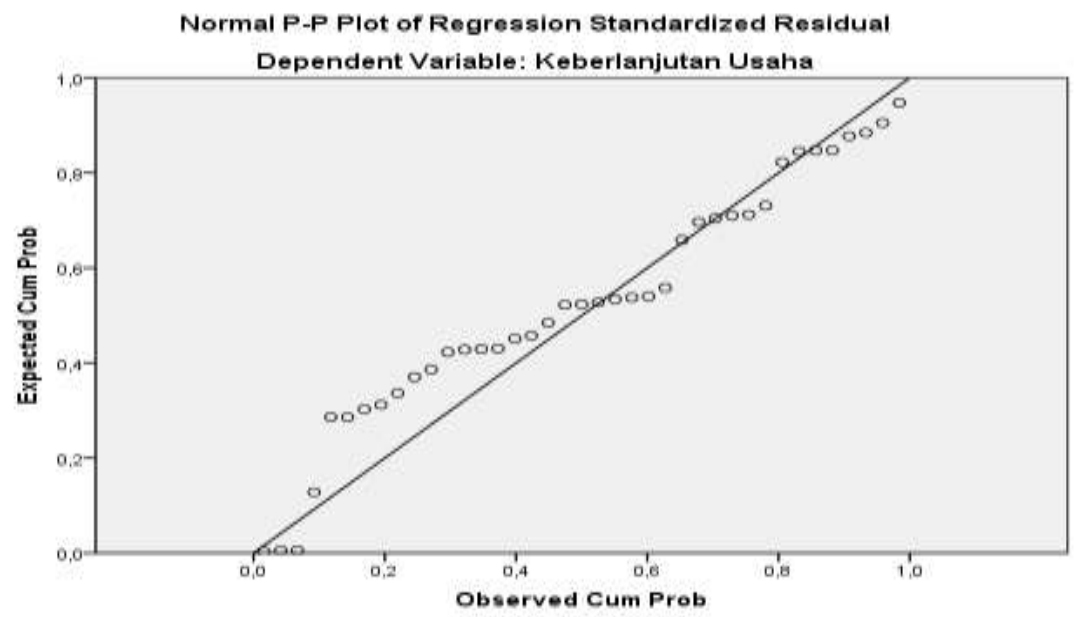

Figure 2. Plotting the Regression Model

Meanwhile, in the multicollinearity test, it is known that there are no multicollinearity symptoms. This is because the variable green accounting practices and organizational size as presented in table 9 have a tolerance value of $0.841>0.100$ and the VIF value shows a value of $1.189<10,000$.

Table 9. Multicollinearity Test Results

\begin{tabular}{lccc}
\hline \multicolumn{1}{c}{ Variable } & Tolerance & VIF & \multirow{2}{*}{ Conclusion } \\
\hline Green Accounting Practices & 0.841 & Value & 1.189 \\
Organizational Size & 0.841 & 1.189 & Not occur \\
\hline
\end{tabular}

For heteroscedasticity testing, heteroscedasticity symptoms were not found, because there was no clear pattern in the scatterplots image as shown in Figure 3, besides that the distribution of the points in the scatterplots image was above and also below the Y-axis (Business Sustainability). This is as Ghazali (2011) states that there is no heteroscedasticity, if there is no clear pattern (wavy, widened then narrowed) in the scatterplots image, and the dots spread above and below the number 0 on the Y-axis as shown below:

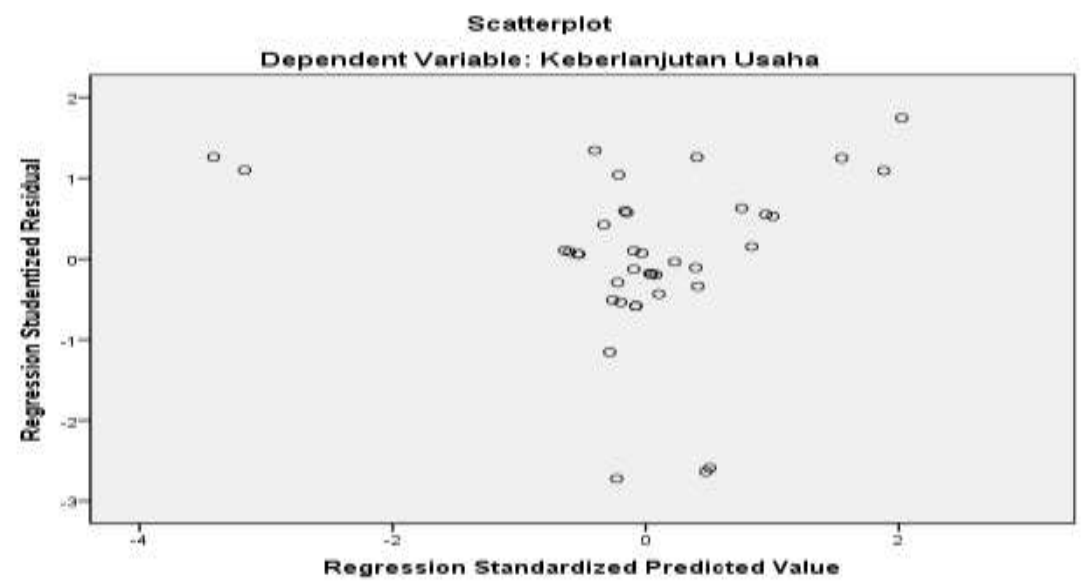

Figure 3. Scatterplot pattern

In the autocorrelation test, the value of Durbin Watson (DW) lies between the value of du (upper limit) to (4-du), namely du (1.597) < Durbin Watson $(1.911)<4$-du (2.403). This shows the absence of autocorrelation symptoms. So, the conclusion of all these tests can be 
concluded that the classical assumption test has been fulfilled, so that it can be continued for the next testing phase, namely hypothesis testing.

\section{Hypothesis Test}

Multiple linear regression test is used in hypothesis testing with the results as presented in table 10 which shows that the green accounting practices carried out by public hospitals in the Malang Raya area affect the business sustainability of the hospitals. The basis is the results of the t-test (Partial Correlation Analysis) where the significance value (Sig.) shows the value of $0.024<0.05$, and the value of $\mathrm{t}$ _Count $2.355>\mathrm{t}$-Table 2.028. Thus, the conclusion is that hypothesis $1(\mathrm{H} 1)$ is acceptable, meaning that the green accounting practices affect business sustainability.

Table 10. t-Test Results (Partial Correlation Analysis)

\begin{tabular}{lccc}
\hline \multirow{2}{*}{ Variable } & \multicolumn{3}{c}{ t-Test Result (Partial) } \\
\cline { 2 - 4 } & t_Table & t_Count & Sig. \\
\hline Green Accounting Practices & 2.028 & 2.355 & 0.024 \\
Organizational Size & 2.028 & 0.072 & 0.943 \\
\hline
\end{tabular}

Meanwhile, for the influence of organizational size on business sustainability, it is known that the Significance value (Sig.) shows a value of $0.943>0.05$, which means that organizational size has no significant effect on business sustainability. This is also supported by the value t_Count $0.072<\mathrm{t}$-Table 2.208 , which means that hypothesis $2(\mathrm{H} 2)$ can be concluded as rejected (not accepted), meaning that organizational size does not affect business sustainability.

Table 11. F Test Results (Simultaneous Test / Multiple Regression Analysis)

\begin{tabular}{cccc}
\hline \multirow{2}{*}{ Variable } & \multicolumn{3}{c}{ F Test Result (Simultaneous) } \\
\cline { 2 - 3 } & F_Table & F_Count & Sig. \\
\hline Green Accounting Practices and Organizational Size & 4.090 & 3.219 & 0.052 \\
\hline
\end{tabular}

For the simultaneous test ( $\mathrm{F}$ test) as presented in table 11, it is known that the Significance value (Sig.) is $0.052>0.05$, and also F_Count 3.219< F_Table 4.090, which means hypothesis $3(\mathrm{H} 3)$ is rejected (not accepted) and explains that the application variable green accounting practices and organizational size together (simultaneously) do not influence the variable of business sustainability.

Whereas in table 12 it is known that the R Square value shows a value of 0.152 and an Adjusted R Square value of 0.105. This shows that the contribution of green accounting practices carried out by public hospitals in Malang Raya and the organizational size of these public hospitals have an influence on business sustainability by only $15.2 \%$. even in a moderate way, the influence is only $10.5 \%$. This means, there are still other factors of $84.8 \%$ or a moderate $89.5 \%$ that can affect the business sustainability of a public hospital in running its business.

Table 12. Results of the Coefficient of Determination

\begin{tabular}{cccc}
\hline Model & $\mathrm{R}$ & $\mathrm{R}$ Square & Adjusted R Square \\
\hline 1 & $0.389^{\mathrm{a}}$ & 0.152 & 0.105 \\
\hline
\end{tabular}

\section{Discussion}

This study discusses the effect of green accounting practices and organizational size on business sustainability in public hospitals in Malang Raya. Of the 39 respondents who were collected from 40 public hospitals that became the population in this study, it resulted that the green accounting practices influenced the sustainability of the hospital's businesses as research 
by Ashari (2019), and Ashari \& Anggoro (2020). This shows that public hospitals in Malang Raya as a public entity as stated by Deegan (2003) have maintained environmental sustainability as an effort to prevent environmental pollution and increase positive perceptions from the community to increase community loyalty to the company which in turn increases sales and profits. companies as researched by Aniela (2012); and Ningsih and Rachmawati (2017); and has a positive impact on company value as in the research of Sawitri (2017) which in turn has an impact on increasing the sustainability of the business company, as evidenced by Hardianti (2017), which is proven by the sustainability of capital, sustainability of human resources, the sustainability of services and sustainability of marketing all of these things can be realized if corporate governance can maintain a balance between economic interests (companies), environmental interests and social interests of the community (Miqdad, 2016). So, this also explains that a hospital in Malang Raya has a level of readiness in socioenvironmental issues by implementing green accounting in its business activities towards a green hospital (Putri, et., al., 2016).

In its application, green accounting practices by public hospitals is based on financial activities, social activities, and environmental activities as a form of responsibility for public hospitals in terms of economic responsibility (profit), social responsibility (people), and environmental (planet) responsibility for its business as Elkington (1997, 2001), Wibisono (2007), and Lako (2018). This refers to the theory or triple-bottom-line of business model initiated by Elkington (1997, 2001), and in line with the provisions of Law Number 36 of 2009 concerning Health, Government Regulation Number 66 of 2014 concerning Environmental Health, and Regulation of the Minister of Health. Republic of Indonesia Number 7 of 2019 concerning Hospital Environmental Health which has the aim of realizing the quality of environmental health in hospitals, to create an environmentally friendly hospital.

In the financial aspect, the green accounting practices are applied to the public hospitals located in Malang Raya by carrying out regular financial reporting, namely presenting financial information related to social and environmental activities, as well as conducting periodic audits of financial reports. In the social aspect, it is necessary to have social responsibility carried out by public hospitals in Malang Raya that are related to products, services, actions that can destroy trust, labor practices, social activities, waste management, and environmentally friendly products. After the social responsibility is carried out, the social activity reporting and the presentation of social costs in the financial report will be carried out as well as periodic social audits. Meanwhile, in the environmental aspect, there are environmental regulations that must be obeyed and the management's attention to the environment shows that the environment is an important thing to protect. The existence of management involvement in environmental issues is indicated by the existence of a special unit formed by general hospital management as well as a budget and work program to deal with environmental problems. There is management responsibility for the environment by formulating hospital policies to deal with hospital waste as a form of responsibility for the environment. Next is the reporting of environmental problems and the presentation of environmental management costs in financial reports and the implementation of regular environmental audits, as well as the legitimacy theory and stakeholder theory which supports the delivery of social and environmental accountability (Deegan, 2004).

While the results of research on organizational size partially do not affect business sustainability at hospitals located in Malang Raya. This is because this study does not distinguish between general hospitals of types A, B, C, and D. In general, compared to small organizations, large organizations can finance and the availability of manpower to carry out their duties and responsibilities. has a goal in reducing the impact of environmental damage caused by the organization's business activities as Prasojo \& Purwanto (2013) in their research. 
So that by reducing the impact on environmental damage, it is expected that it will have an impact on the business sustainability of public hospitals in running their business. Thus, the results of this study are in line with research from Prasojo \& Purwanto (2013); Azzahra, et., Al., (2015); and Septiana, et., al., (2018), which state that the size of the organization has no effect in terms of disclosing information that has an impact on business sustainability.

To study the effect of green accounting practices and organizational size simultaneously, it is known that in this case it has no effect on business sustainability. This is because (a) the effect of green accounting practices on business sustainability is only $12.7 \%$ in a moderate manner based on the results of Ashari \& Anggoro (2020), and (b) is also due to the absence of an influence of organizational size on business sustainability as the results of this study and (c) the contribution of the impact on business sustainability is only $10.5 \%$ in a moderate manner. This contribution decreased from $12.7 \%$ to $10.5 \%$. Thus, it causes no effect between the green accounting practices and organizational size on the sustainability of business carried out simultaneously (together).

\section{CONCLUSIONS AND SUGGESTION}

After conducting a study and discussion, this study concludes that partially the green accounting practices affect business sustainability, while organizational size does not affect business sustainability. Even simultaneously, the application of green accounting and organizational size does not affect business sustainability. This is indicated by the small impact contribution value.

This study has limitations that lie in the study of the object of research that does not differentiate between types or classes of public hospitals, where the hospitals are type A, type $\mathrm{B}$, type $\mathrm{C}$, and type $\mathrm{D}$, as well as the indicators used in the variable of green accounting practices, are based on several previous studies that have been related to financial aspects, social aspects, and environmental aspects.

For further research it is suggested that the object of research be carried out in all hospitals in the territory of Indonesia to provide better results to distinguish between public hospitals that are type A, type B, type C, and type D. Of course, to facilitate the research process better to cooperate with professional organizations that overshadow public hospitals to be able to facilitate the research. Besides, the object of research can also be carried out at agencies or business organizations other than hospitals that are concentrated on environmental and social problems. Another suggestion is the addition of research variables that correlate with the green accounting practices and business sustainability, with other statistical software tools such as using SmartPLS and WarpPLS. With the results of this study, it is better if now public hospitals throughout Indonesia have not implemented green accounting to immediately implement it, and if there are obstacles in the green accounting practices, it is hoped that IAI as an institution that has the authority to formulate Financial Accounting Standards can prepare standards as green accounting reporting is in Green Accounting Standards. Also, for the classification of hospitals related to type or class, other indicators that correlate with hospital service facilities can be considered.

\section{REFERENCES}

Aniela, Y. (2012. Peran Akuntansi Lingkungan Dalam Meningkatkan Kinerja Lingkungan dan Kinerja Keuangan Perusahaan. Berkala Ilmiah Mahasiswa Akuntansi, 1 (1), 15-19.

Arikunto, S. (2005). Manajemen Penelitian. Jakarta: Rineka Cipta. 
Ashari, M.H. (2019). Mewujudkan Keberlanjutan Usaha (Business Sustainability) dengan Penerapan Green Accounting (Akuntansi Hijau) pada Rumah Sakit Umum (Public Hospitals) di Malang Raya. Tesis. Pascasarjana Magister Akuntansi Universitas Gajayana Malang.

Ashari, M.H., U. Muawanah, \& O. Lisa. (2020). Keterkaitan Ukuran Organisasi dan Pemahaman Manajemen terhadap Penerapan Akuntansi Hijau (Green Accounting). Jurnal Informasi, Perpajakan, Akuntansi dan Keuangan Publik (JIPAK) Universitas Trisakti. 15(1), 33-54. doi : 10.25105/jipak.v15i1.6186

Ashari, M.H., \& Y. Anggoro. (2020). Implementation of Green Accounting in Business Sustainability at Public Hospitals in Malang Raya. International Journal of Multicultural and Multireligious Understanding (IJMMU) ISSN 2364-5369, 7 (10), 391 403, November 2020. doi: 10.18415/ijmmu.v7i10

Astiti, W. (2014). Implementasi Green Accounting berbasis University Social Responsibility (USR) di Universitas Negeri Yogyakarta. Jurnal Nominal, III (2), 134-149

Ayyagari, M., A. Demirguc-Kunt, \& V. Maksimovic. (2011). Small vs Young Firms across the World: Contribution to Employment, Job Creation, and Growth. The World Bank, Development Research Group, Finance, and Private Sector Development Team, 1-41.

Azzahra, Z. \& B. Susanto. (2015). Ukuran Perusahaan, Pernyataan Standar Akuntansi dan Manajemen Lingkungan terhadap Pelaksanaan Akuntansi Lingkungan (The Size of The Company, A Statement of Accounting Standards, and Environmental Management on The Implementation of Environmental Accounting). Jurnal Analisis Bisnis Ekonomi, 13 (1): 84-93

Budiaji, W. (2013). Skala Pengukuran dan Jumlah Respon Skala Likert (The Measurement Scale and The Number of Responses in Likert Scale). Jurnal Ilmu Pertanian dan Perikanan, 2 (2).127-133.

Chahal, H. \& Sharma, R.D. (2006). Implications of Corporate Social Responsibility on Marketing Performance: A Conceptual Framework. Journal of Services Research, 6 (1), 215-228

Cohen, L., L. Manion, \& K. Morrison. (2007). Research Methods in Education. Sixth Edition. New York: Routledge.

Deegan, C. (2003). Environmental Management Accounting: An introduction and case studies for Australia, Victoria. Environment Protection Authority. Australia: Institute of Chartered Accountants in Australia.

Deegan, C. (2004). Financial Accounting Theory. Australia: McGraw-Hill.

Dunk, A.S. (2002). Product Quality, Environmental Accounting, and Quality Performance. Accounting, Auditing \& Accountability Journal. MCB Up Limited, 15(5), 719-732. 
Elkington, J. (1997). Cannibals with Forks-Triple Bottom Line of 21 Century Business. Stoney Creek, CT: New Society Publishers.

Elkington, J. (2001). The Chrysalis Economy: How Citizen CEOs and Corporations Can Fuse Values and Value Creation. United Kingdom: Capstone Publishing.

Frost, G.R. \& M. Seamer. (2002). Adoption of Environmental Reporting and Management Practices: An Analysis of New South Wales Public Sector Entities. Financial Accountability Management, 18 (2), 103-127.

Ghazali, I. (2011). Aplikasi Analisis Multivariat Dengan Program SPSS. Semarang: Badan Penerbit Universitas Diponegoro.

Government Regulation Number 66 of 2014 concerning Environmental Health. Jakarta

Hackston, D., \& M.J. Milne. (1996). Some Determinants of Social and Environmental Disclosures in New Zealand Companies. Accounting, Auditing \& Accountability Journal, 9 (1),77-108.

Hamzah, A. (2019). Metode Penelitian dan Pengembangan (Research \& Development): Uji Produk Kuantitatif dan Kualitatif, Proses dan Hasil Dilengkapi Contoh Proposal Pengembangan Desain Uji Kualitatif dan Kuantitatif. Malang: Literasi Nusantara Abadi.

Handayani, N. (2007). Modal Sosial dan Keberlangsungan Usaha (Studi Deskriptif Kualitatif Tentang Keterkaitan Hubungan Modal Sosial dengan Keberlangsungan Usaha Pengusaha Batik di Kampung Kauman, Kelurahan Kauman, Kecamatan Pasar Kliwon, Surakarta). Skripsi. Universitas Sebelas Maret, Surakarta.

Hansen, D.R. \& M.M. Mowen. (2009). Akuntansi Managerial. Jakarta: Salemba Empat.

Hardianti. (2017). Peran Green Accounting dalam Upaya Mencegah Pencemaran Lingkungan untuk Menunjang Keberlangsungan Usaha (Studi pada PTPN Persero Pabrik Gula Takalar). Skripsi. Universitas Islam Negeri Alauddin, Makassar.

Hati, R.P. (2018). Analisis Penerapan Green Accounting Berbasis University Social Responsibility (USR) pada Universitas Riau Kepulauan dan Universitas Internasional Batam. Measurement Journal, 12(1), 121-13.

Hofmans, J., P. Theuns, \& O. Mairesse. 2007. Impact of the Number of Response Categories on Linearity and Sensitivity of Self-Anchoring Scales: A Functional Measurement Approach. Methodology, 3 (4), 160-169.

Ijma, N. Haris \& N. Yusnita. (2018). Pengaruh Ukuran Perusahaan, Profitabilitas dan Porsi Kepemilikan Publik terhadap Environmental Disclosure (Studi pada Perusahaan Logam dan Mineral Lainnya yang terdaftar di Bursa Efek Indonesia). e-Jurnal Katalogis, 6(4), $1-9$.

International Organization for Standardization (ISO) series 14010-14019 about Environmental Auditing (Audit Lingkungan). Jakarta 
THE EFFECT OF GREEN ACCOUNTING PRACTICES AND ORGANIZATIONAL SIZE IN BUSINESS

SUSTAINABILITY OF PUBLIC HOSPITALS

Muhammad Hasyim Ashari, and Yudhi Anggoro

Law Number 20 of 2008 concerning Micro, Small and Medium Enterprises. Jakarta

Law Number 36 of 2009 concerning Health. Jakarta

Lako, A. (2015) a. Berkas CSR bukan Fiksi. Edisi Pertama. La Tofi Publishing Enterprises.

Lako, A. (2015) b. CSR Investasi Strategis. Investor Daily. Jakarta

Lako, A. (2018). Akuntansi Hijau: Isu, Teori dan Aplikasi. Jakarta: Salemba Empat.

Mahmud. (2011). Metode Penelitian Pendidikan. Bandung: Pustaka Setia.

Miqdad, M. (2016). Membangun Corporate Sustainability melalui Implementasi Green Accounting untuk Merespon Kebutuhan Pasar. Prosiding SNA MK, 28-09-2016: 51-62

Morrisan. (2012). Metode Penelitian Survei. Edisi Pertama. Jakarta: Kencana.

Ningsih, W.F., \& R. Rachmawati. (2017). Implementasi Green Accounting dalam Meningkatkan Kinerja Perusahaan. Journal of Applied Business and Economics,4(2), $149-158$

Panggabean, R.R. \& H. Deviarti. (2012). Evaluasi Pengungkapan Akuntansi Lingkungan Dalam Perspektif PT Timah (Persero) Tbk. Binus Business Review, 3 (2), 1010-1028.

Pernyataan Standar Akuntansi Keuangan No.1 tentang Penyajian Laporan Keuangan. Ikatan Akuntan Indonesia (IAI) - Institue of Indonesia Chartered Accountants. Jakarta

Pinasti, M. (2001). Penerapan Informasi Akuntansi dalam Pengelolaan Usaha para Pedangan Kecil di Pasar Tradisional Kabuapaten Banyumas. Jurnal Ekonomi, Bisnis dan Akuntansi, 3(1): 1-21.

Prasojo, T.B., dan A. Purwanto. (2013). Faktor-Faktor yang Mempengaruhi Pelaksanaan Akuntansi Lingkungan (Studi pada KLH/BLH, Dinkeb, dan PDAM Kabupaten/Kota di Provinsi Jawa Tengah). Diponegoro Journal of Accounting, 2 (1), 1-10.

Puspitaningtyas, Z. (2016). Mengakuntasikan Corporate Social Responsibility: Pengukuran dan Penyajian Biaya Sosial dalam Laporan Keuangan. Prosiding Seri Ekonomi Konferensi Nasional PkM CSR ke-2. LPPM Universitas Pelita Harapan Tagerang, 2016: 94-103.

Putri, C.F., D. Purnomo \& E. Astuti. (2016). Analisis Kesiapan Rumah Sakit Menuju Ramah Lingkungan (Green Hospital) di Kota Malang. Seminar Nasional Inovasi dan Aplikasi Teknologi di Industri (SENIATI) 2016. Institut Teknologi Nasional Malang. 12-17.

Regulation of the Minister of Health of the Republic of Indonesia Number 7 of 2019 concerning Hospital Environmental Health. Jakarta

Rezaee, Z. (2015). Business Sustainability: Performace, Compliance, Accountability, and Integrated Reporting. New York: A Greenleaf Publishing Book. 
Sawitri, A.P. (2017). Analisis Pengaruh Pengungkapan Akuntansi Lingkungan dan Kinerja Lingkungan Terhadap Nilai Perusahaan. Seminar Nasional \& Call For Paper, FEB Unikama: Peningkatan Ketahanan Ekonomi Nasional dalam Rangka Menghadapi Persaingan Global. Malang 17 Mei 2017: 177-187

Septiana, N.L.D., I.G.C. Putra, \& L.K. Merawati. (2018). Faktor-Faktor yang Mempengaruhi Pelaksanaan Akuntansi Lingkungan pada Hotel Bintang Lima di Kabupaten Badung. Jurnal Undhirabali, 13 (2), 119-131.

Setiawan, J. (2014). Kepedulian dan Pengetahuan Pelaku Bisnis Mengenai Green Accounting (Studi Kasus pada Pedagang Pasar di Kota Salatiga). Kertas Kerja. Universitas Kristen Satya Wacana Salatiga.

Siregar, S. (2013). Statistik Parametrik Untuk Penelitian Kuantitatif: Dilengkapi dengan Perhitungan Manual dan Aplikasi SPSS Versi 17. Jakarta: Bumi Aksara.

Suaryana, A. (2011). Implementasi Akuntansi Sosial dan Lingkungan di Indonesia. Jurnal Ilmiah Akuntansi dan Bisnis, 6 (1), 1-26.

Sugiyono. (2005). Memahami Penelitian Kualitatif. Bandung: Alfabeta.

Sugiyono. (2010). Metode Penelitian Pendidikan Pendekatan Kuantitatif, Kualitatif, dan R\&D. Bandung: Alfabeta.

Susilo, J. (2008). Green Accounting di daerah Istimewa Yogjakarta: Studi Kasus antara Kabupaten Sleman dan Kabupaten Bantul. JAAI, 12 (2),149-165.

Teoh, Hai-Yap, Thong, \& Gregory. (1984). Another Look at Corporate Social Responsibility and Reporting: An Empirical Study in A Developing Country. Accounting and Organizations and Society. 9 (2), 189-206.

Wibisono, Y. (2007). Membedah Konsep \& Aplikasi CSR (Corporate Social Responsibility). Jakarta: Gramedia.

Yousef, F.H. (2003). Green Accounting in Developing Countries: The Case of UAE and Jordan. Managerial Finance. 29 (8), 37-45. 